\title{
Parthenium hysterophorus. L. (Asteraceae): A Boon or Curse? (A Review)
}

\author{
ARCHANA JOSHI ${ }^{1}$, R.K. BACHHETI ${ }^{2 *}$ ASHUTOSH SHARMA ${ }^{2}$ and RITU MAMGAIN ${ }^{2}$ \\ ${ }^{1}$ Department of Environmental Science, Graphic Era University, Dehradun, India. \\ ${ }^{2}$ Department of Chemistry Graphic Era University, Dehradun, India. \\ ${ }^{*}$ Corresponding author E mail: rkbfri@ rediffmail.com \\ http://dx.doi.org/10.13005/ojc/320302
}

(Received: April 29, 2016; Accepted: June 02, 2016)

\begin{abstract}
Parthenium hysterophorus (Linn.) is violent every where annual, herbivorous weed, commonly found in America but presently invaded in four continents. It shows hazardous effect on human health, livestock as well as it reduces the crop production due to its allelopathic effect. Partheniun with other constituents discussed are the cause behind the intimidating role of this weed. Inspite of these drawbacks the weed is traditionally known for the treatment of wounds, fever, ulcerated sores and malaria. It can also be used to increase the agricultural productivity and for the elimination of heavy metals from soil as well as from water to reduce pollution. The main aim of this review article is to summarise the main positive and negative effects of the Parthenium hysterophorus.
\end{abstract}

Keywords: Parthenium hysterophorus, Allelopathic effect, weeds.

\section{INTRODUCTION}

From the ancient time human being depends on plants species for their different needs. Various reports are available on utilization of various parts of the plants including weeds ${ }^{1,2,3}$. Parthenium hysterophorus (Linn.) (Asteraceae) is a herbaceous annual of Asteraceae family. At present $P$. hysterophorus (Linn.) has captured urban and agriculture zones and become obnoxious weed out of seven one of the seven most intolerable weeds of the world ${ }^{4}$ It is commonly called congress weed, carrot weed, star weed, feverweed, white top, chatak chandani, bitter weed, ramphool, gajar ghass etc.

The weed is highly flexible to adverse environmental conditions, and also a successful invader in any open land. It easily establishes its own colony at the cost of other vegetation. The plant is very creative seed producer, with up to 25,000 seeds per plant ${ }^{5}$ and with an enormous seed bank, estimated at 2,00,000 seeds $\mathrm{m}^{-1}$ in abandoned fields ${ }^{6}$ Furthermore, germination of seeds can take place anytime if appropriate moisture level given. 
The seeds of the plant remain feasible for a long period of time and can even survive under harsh environmental conditions ${ }^{7}$. Non dormancy and extreme light weight seeds help its extensive spread and establishment. It is an annual with fast maturity level. Generally, flowering takes place when they are 4 to 8 weeks old and flower for several months. The weed can germinate grow mature \& set seeds, complete its life cycle in 4 weeks even in under unfavourable conditions such as drought. The weed also has a very high instructive potential ${ }^{8}$.

\section{Geographical Distribution}

Parthenium weed is naturally found in tropical and subtropical America, from southern United State of America, through southern Brazil and northern Argentina ${ }^{9}$. The weed was accidentally introduced to Asia, Africa and Australia. It is widely known that the weed in India for the first time was recorded by Rao from Puna, (Maharashtra) and blame goes to the USA PL 480 scheme wheat seeds with which the seeds of the $P$. hysterophorus came to India accidently ${ }^{10}$. Since then the weed spread to most part of the Indian sub-continent, including Pakistan. It has also spread to southern China, Taiwan and Vietnam in Asia ${ }^{11}$. It has invaded several African countries; the weed was first introduced accidentally into Ethiopia in 1970s and further spread to Kenya, Mozambique and South Africa ${ }^{12,13}$.

\section{Phytochemistry}

The phytochemistry of $P$. hysterophorus has attracted considerable interest mainly due to the presence of toxic compounds. Chemical investigation has shown the presence of parthenin (1), coronopilin (2), $2 \beta$-hydroxycoronopilin (3), tetraneurin-A (4), hysterophorin, hysterin, dihydroisoparthenin, hymenin ${ }^{15}$. One study shows that, isolated $8 \alpha$-Epoxymethacryloxyparthenin, $8 \alpha$-epoxymethacryloxy-11,13-dihydroparthenin, and $8 \alpha$-epoxymethacryloxyambrosin from its air dried leaves ${ }^{16}$. Another study shows that, isolated three pseudoguaianolides $11 \beta-\mathrm{H}, 13-$ dihydroparthenin $\left(R_{1}=\mathrm{OH}, \mathrm{R}_{2}=\mathrm{H}, 5\right)$, 13-methoxy-11, 13dihydroambrosin $\left(\mathrm{R}_{1}=\mathrm{H}, \mathrm{R}_{2}=\mathrm{OMe}, 6\right)$ and 13methoxy-11,13-dihydroparthenin $\left(\mathrm{R}_{1}=\mathrm{OH}, \mathrm{R}_{2}=\right.$ OMe, 7$)^{17}$.

Another study shows that, isolated $8 \beta$-acetoxyparthenin from the aerial part, a new epoxy-sesquiterpenoid parthoxynol ${ }^{18}$ and a highly oxygenated pseudoguaianolide $8 \beta$-acetoxyhysterone $\mathrm{C},{ }^{19}$ from flower, two minor pseudoguaianolides parthenin- $8 \beta$-isopentanoate and parthenin-8 $\beta$ isopentenoate from whole plant of $P$. hysterophorus ${ }^{20}$ Two new pseudoguaianolide type sesquiterpene lactones, named deacetyltetraneurin A (8) and hysterone $E(9)$, along with scopoletin (10), $8 \beta$-hydroxycoronopilin, and conchasin A (11) were also isolated from flower ${ }^{21,22}$. One report shows that leaves of $P$.hysterophorus contained dihydroparthenin and 13-methoxydihydrocoronopilin ${ }^{23}$. A study shows that isolated stigmasterol, $b$-sitosterol, isoparthenin, coronopilin and 11, 13-dihydroparthenin and chemical investigation ${ }^{24}$ afforded a new aliphatic ester hentriacontanyl eicosanoate from aerial parts of $P$. hysterophorous. Four new pseudoguaianolides, hysterones A-D (12-15) ${ }^{25}$ and four acetylated pseudoguaianolides were recently obtained from the flowers. Sesquiterpenoid, charminarone (16), the first seco-pseudoguaianolide, was isolated along with other well-known compounds from the whole plant of $P$. hysterophorus ${ }^{26}$. Along with above mentioned compounds ambrosin, flavonoids (quercelagetin 3, 7-dimethylether; 6 hydroxyl kaempferol 3-0) fumaric acid (17), p-hydroxybenzoin (18), vanillic acid (19), caffeic acid (20), $p$-courmaric acid (21), $p$-anisic acid (22), chlorogenic acid (23), ferulic acid (24), sitosterol and some unidentified alcohols were also isolated. The chemical compound of the oil of $P$. hysterophorus. L. was investigated by GC-MS and $78 \%$ of the oil was characterized. The oil contains 63 constituents. The major constituents identified were bornyl acetate (9.15\%), geraniol $(7.53 \%)$ and Phenyl acetonitrile (7.85\%) and $b$-myrcene (3.23\%) with other known sesquiterpene lactones ${ }^{27}$. The main phenolic acids obtained are caffeic acid, anisic acid, ferulic acid, Borneol, camphor and n-hydroxybenzoic $\operatorname{acid}^{28}$.

\section{Effects of Parthenium hysterophorus: On living organisms}

Earlier investigations had revealed that livestock was facing a serious health problems livestock in Parthenium invaded areas. Incorporation of $P$. hysterophorus into the diet of live stock was found to cause chronic or acute toxicity depending upon the quantum of the weed ingested ${ }^{29}$. In artificial feeding tests buffalo, bull calves accepted the weed alone or in mixture with green fodder; majority of 
animals under test developed severe dermatitis as well as toxic symptoms and died within 8-30 days. Lesions were found subsequently in the gastrointestinal tract, liver and kidney ${ }^{30}$. One report shows that the weed taints the milk and meat of animals ${ }^{31}$. When parthenium one of the major sesquiterpene of $P$. hysterophorus was tested against Rattus norvegicus, it showed symptoms like laboured breathing and dizziness. Its Median lethal dose $\left(L_{50}\right)$ in $R$. norvegicus was found to be 47.79 $\mathrm{mg} / \mathrm{kg}^{32}$. The pharmacological effects of $10 \%$ cold aqueous extract of $P$. hysterophorus flowers was investigated on dog blood pressure and respiration, perfused frog heart, and isolated rabbit duodenum. The extract exhibited hypotensive response, cardiac depressant effect, and mild spasmogenic action on intestinal smooth muscles. Due to the release of histamine in the animal body the flower extract potentiated the hypotensive action of histamine ${ }^{33}$. Parthenium reduces production from livestock by causing various health problems and also by causing scarcity of animal fodder by invading pasture lands. Parthenium can also affect the psychological behavior of animals ${ }^{34}$. It is also responsible to cause human health problems like dermatitis, hay fever, asthma, rhinitis, irritation to eyes, stomach pain, stretching and cracking of skin and breathing problem ${ }^{35}$. Continuous exposure to the pollen grains of $P$. hysterophorus causes allergic bronchitis in human beings ${ }^{36,37,38,39,40}$.

Parthenium indirectly effects human health by their interactions with disease-transmitting vectors. One report shows that the toxic impact present on P. hysterophorus positively impact on the survival \& energy reserves of malaria vector Anopheles gambiae. Females Anopheles gambiae survived better \& accumulated energy reserves when fed on P. hysterophorus ${ }^{41}$.

\section{On Agriculture Productivity}

It inhibits the germination and growth of other plants due to allelopathy effect. Allelopathy is the phenomenon in which living or dead plant material including decaying litter releases chemicals that inhibit the growth of associated plants. Aqueous extracts of leaves and inflorescence inhibit the germination and growth of barley, corn, wheat and peas as reported by various authors ${ }^{42,43}$. If parthenium is not controlled, Sorghum reduces its yield in
Ethiopia ${ }^{44}$. Parthenin, oleanolic acid and embelin are the components which are responsible for reduced germination ${ }^{45,46,47}$. When parthenium extracts were directly sprayed on crop plants, survival of the cell and chlorophyll content were clearly reduced. The allelopathic effect of $P$. hysterophorus extract on the meristametic cell of onion exerts mitotic depression causing chromosomal abnormalities such as fragments, stickiness nuclear vacuolation, bridge, laggards \& micronuclei. The suppression of DNA content due to Parthenium causes deviation of normal metabolic activity which is a potential threat to genomic balance ${ }^{48}$. Similar adverse effect of parthenium residue have been reported on growth of Brassica compestris, B. oleracea, B. rapa, Cicer arietinum and Raphanus sativus ${ }^{49}$. Allelotoxic effect of parthenin on Vicia faba $L^{50}$.

Residues of parthenium leaf and flower were reported to have toxic effect to aquatic plants like salvinia ${ }^{51}$. The weed has capacity to extract nutrients even from nutrient deficient soil and in crop land can be reduce up to $40 \%$ in yield ${ }^{52}$. Various reports have declared it as toxic weed due to its potential to decrease the crop productivity, fodder scarcity, biodiversity depletion and health problems for livestock and human causing hay fever, skin problems and asthma ${ }^{53}$. It reduces agricultural production by suppressing agricultural yield from crops and animals ${ }^{54}$.

\section{On Biodiversity}

The weed has the potential to disturb the natural ecosystem, as it can grow throughout the year in almost all drastic conditions suppressing native vegetation. Owning the absence of effective natural enemies, its alleopathic effect as well as photo and thermo insensitivity, it is a threat for natural diversity ${ }^{55,56}$. The weed is attributed to be mainly responsible for total habitat change in native Australian grasslands, open wood-lands, river banks and flood plains due to its invasion ${ }^{57}$. The successful progress of biological control depends upon suitable policy, legislative, funding and infrastructure frameworks. Australia has advantages such as being a nation-continent, having achieved early biocontrol successes known to the public, having a unique native flora and enjoying political enthusiasm for biological control ${ }^{58}$. Similarly Parthenium invaded in national wildlife parks have also been reported in 


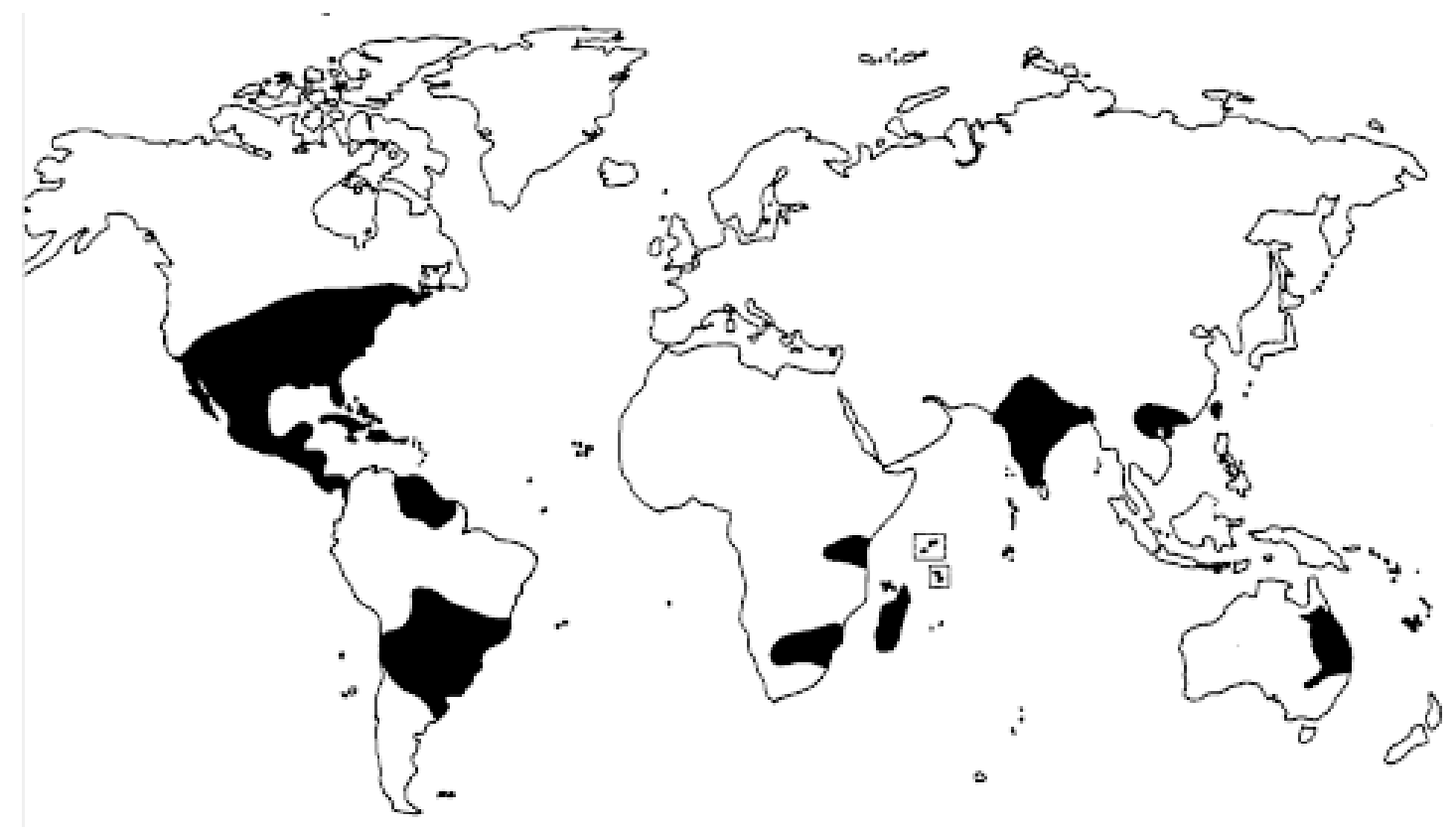

Geographical Distribution of Parthenium hysterophorus in $1994^{14}$

southern India ${ }^{59}$. Parthenium spread over agricultural land, grazing land and highways. It competes with crops cultivated in land at a rapid rate as well as also deplete the nutrient content of soil. Number of seeds in parthenium is very high and it can be disperse by air, water, animal etc. So able to colonize new areas. Moreover, the weed spread all over India such as Punjab, J\&K and it replaces the local flora of those places $^{60,61}$. Some of the allelochemicals are washed away by water and enter the aquatic ecosystem which shows adverse effect on aquatic plants ${ }^{62}$. The biological control agents and suppressive plants can be combined successfully to improve the management of parthenium weed to a level that is better than either management option alone ${ }^{63}$. Allelochemicals released from parthenium is capable of changing the physicochemical characteristics of the soil. It affects the moisture content, temperature, $\mathrm{pH}$, organic matter, carbon, nitrogen and phosphorus content and soil microbial activity ${ }^{64,65,66}$. The change in property of the soil due to introduction of allelochemicals affects the reproduction, growth and survival of other nearby plant ${ }^{67,68,69,70}$. Generally parthenium is intended to pose a serious threat to the biodiversity by invading new surroundings and by reducing or totally replacing the indigenous species where it causes total habitat change ${ }^{71}$.

\section{Biological activity of parthenium}

Parthenium is used as traditional medicine in the Caribbean and Central America ${ }^{5}$. It is used for the treatment of wounds, ulcerated sores, fever, anaemia, heart problems and malaria ${ }^{72}$. One study shows that sublethal doses of $P$. hysterophorus major reduction in glucose level in the blood of diabetic $(\mathrm{P}<0.01)$ rats $^{73}$. It reveals that the active fraction of $P$. hysterophorus. $L$ flower extract is very capable for developing standardized phytomedicine for diabetes mellitus. A study shows that the antitumor activity in the weed. It was found that the methanolic extract of $P$. hysterophorous show antitumor effect in host mice bearing transplantable lymphocytic leukaemia ${ }^{74}$. The extract could either cure mice completely or increase their survival time after they had been injected with cancer cells ${ }^{75}$. Parthenium has shown capable antidote against hepatic amoebiasis ${ }^{76}$. One study shows that allelopathic prospective of $P$. hysterophorus $L$ against pathogenic fungal species (Drechslera hawaiiensis (M.B.Ellis), Alternaria alternata (Fr.) Keissl and Fusarium monilifrome) ${ }^{4}$. Aqueous extracts prepared from the aerial parts of $P$. hysterophorus in liquid malt extract medium showed the inhibited growth of all the test pathogenic species by lower concentrations, while aqueous extracts of higher concentrations stimulated biomass production 
of test fungal species. The ethnobotanical efficacy of various solvent extract of Parthenium against both human and plant pathogenic bacteria showed varied level of inhibition ${ }^{77}$. A pseudoguaianolide isolated from aerial parts of $P$. hysterophorus (Linn) was shows the antibacterial activity against three Gram negative, one Gram positive and some human pathogenic bacteria ${ }^{78}$. Hentriacontanyl eicosanoate an aliphatic ester isolated from $P$. hysterphorus has been evaluated for its antibacterial activity against Staphylococcus aureus, Escherichia coli, Pseudomonas aeruginosa and antifungal activity against Aspergillus niger, Candida albicans and Fusarium oxysporum ${ }^{24}$. Parthenolide a constituent isolated from $P$. hysterophorous showed significant inhibition on Tobacca mosaic virus in vitro ${ }^{79}$. Various fractions obtained from $P$. hysterophorous showed anti-inflammatory activities ${ }^{80}$.<smiles>C=C1C(=O)O[C@H]2[C@@H]1CC[C@@H](C)[C@@]1(O)C=CC(=O)[C@@]21C</smiles>

Parthenin (1)<smiles>C=C1C(=O)OC2C1CCC(COC(C)=O)C1(O)CCC(=O)C21C</smiles>

Tetraneurin (4)

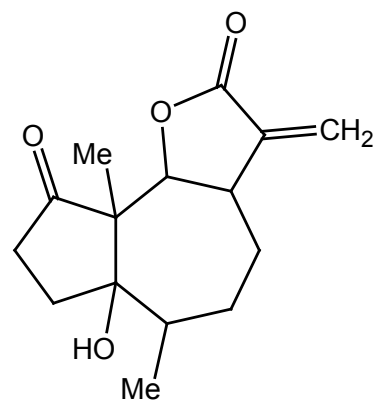

Coronopilin (2)<smiles>C=C1C(=O)O[C@H]2[C@@H]1CC[C@H](C)[C@@]1(O)[C@@H](O)CC(=O)[C@@]21C</smiles>

2 -Hydroxycoronopilin (3)<smiles>C=C1C(=O)O[C@H]2[C@@H]1CC[C@H](CO)C1(O)CCC(=O)[C@@]21C</smiles>

Deacetyltetraneurin A (8)<smiles>[R]CC1C(=O)O[C@H]([C@@]2(C)C(=O)CCC2([R])C(C)C)[C@H]1C</smiles>

$\mathbf{R}^{1}=\mathbf{O H}, \mathbf{R}^{2}=\mathbf{H}(5)$

$\mathbf{R}^{1}=\mathbf{H}, \mathbf{R}^{2}=$ OMe (6)

$\mathbf{R}^{1}=\mathbf{O H}, \mathbf{R}^{2}=$ OMe (7)<smiles>C[C@H]1CC[C@@H]2[C@H](OC(=O)[C@@H]2C)[C@@]2(C)C1=C[C@@H](O)[C@H]2O</smiles>

Hysterone E (9)<smiles>COc1cc2ccc(=O)oc2cc1O</smiles>

Scopoletin (10)<smiles>C=C1C(=O)O[C@H]2[C@@H]1CC[C@@H]1CO[C@@H]3CC(=O)[C@]2(C)[C@]13O</smiles>

Conchasin A (11) 
Potential Use of Parthenium in Agriculture

Parthenium can be used as a green manure. In the ratoon rice crop parthenium green leaf manure was superior in influencing the plant height. Similarly, it produces the highest number of filled grains in comparison to main crop. Among the green leaf manure tried, the residual effect for dry matter production was the highest ${ }^{81} 3 \%$ parthenium green manure produces the highest root and shoot biomass in maize, which was significantly greater

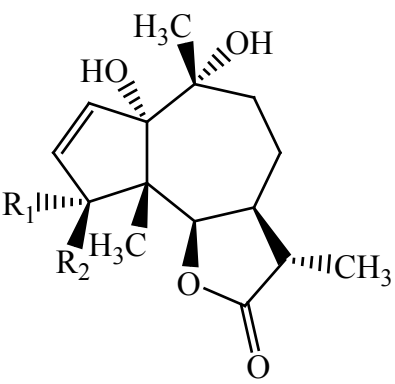

$\mathbf{R}_{1}, \mathbf{R}_{\mathbf{2}}=\mathbf{O}$ (12)

$\mathbf{R}_{1}=\mathbf{H}, \mathbf{R}_{2}=$ OH (13)<smiles>O=C(O)/C=C/C(=O)O</smiles>

Fumaric acid (17)<smiles>O=C(O)/C=C/C(=C/C=C/O)/C=C/O</smiles>

Caffeic acid (20)

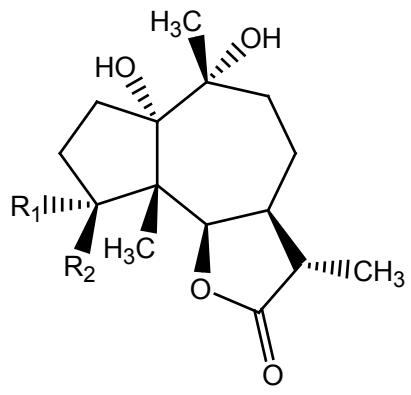

$\mathbf{R}_{1}, \mathbf{R}_{2}=\mathbf{O}$ (14)

$\mathbf{R}_{1}=\mathbf{H}, \mathbf{R}_{2}=\mathbf{O H}$ (15)<smiles>O=C(c1ccccc1)C(O)c1ccccc1</smiles>

p-Hydroxybenzoin (18)<smiles>O=C(O)/C=C/c1ccc(O)cc1</smiles>

p-Coumaric acid (21)<smiles>CC(=O)CCC1=C(C)C(=O)O[C@H]2C(=O)CCC(=O)C12C</smiles>

Charminarone (16)<smiles>COc1cc(C(=O)O)ccc1O</smiles>

Vanillic acid (19)<smiles>COc1ccc(C(=O)O)cc1</smiles>

p-Anisic acid (22)<smiles>O=C(/C=C/c1ccc(O)c(O)c1)OC1CC(O)(C(=O)O)CC(O)C1O</smiles>

Chlorogenic acid (23)<smiles>COc1cc(CCC(=O)O)ccc1O</smiles>

Ferullic acid (24) 
than that obtained in the control and equivalent to that obtained in the NPK fertilizer treatments ${ }^{82}$. Parthenium can be used as an insecticide and biopesticide. Isolated compounds from various species of Parthenium were found to inhibit larval growth. It was observed that sesquiterpene lactones from Parthenium inhibit the growth of Heliothis zea insects. In comparision to unsubstituted ambrosanolide analogues, those oxygenated at C-14 and/or C-15 (parthenolides) was better inhibitory ${ }^{83}$. Roots and stems of $P$. hysterophorous cause the mortality of mosquito larvae but mechanism still not known ${ }^{84}$.

One report shows that parthenium contain high nitrogen, phosphorus and potassium (N, P and $\mathrm{K})^{85}$. One report shows that Parthenium composted pre-flowering has higher nitrogen content $(2.95 \%)$ compared to poultry manure $(2.02 \%)$, vermi compost $(1.21 \%)$ and farm yard manure $(0.54 \%)^{86}$. Similar study has shown that Parthenium compost has higher phosphorus content $(0.82 \%)$ compared to FYM $(0.26 \%)$ but lower in comparision to poultry manure $(1.6 \%)$ and vermi compost $(0.86 \%)$. Its potassium content is also higher (1.39\%) compared to vermi compost $(0.55 \%)$ and FYM $(0.34 \%)$ but lower in comparison to poultry manure (1.42\%). With increasing decomposition period the toxicity of Parthenium reduces. Parthenium composite with other plant materials reduces its allelopathic inhibition potential on seed germination and seedling growth of the model plant lettuce. This fact explained that composting Parthenium with other less or no allelopathic potential plant materials reduces the amount of allelochemicals released into the soil and the corresponding allelopathic inhibition potential ${ }^{10}$. One report shows that $25 \%$ parthenium and $75 \%$ cow dung containing waste mixtures for optimum growth and reproduction of Eisenia fetida and hence $P$. hysterophorous can be used as feedstock for vermicomposting ${ }^{56}$. Parthenium is among other inhibitors relevant for residue allelopathy as simulated under laboratory condition by delaying germination and reducing plant growth ${ }^{87,43}$. The use of $P$. hysterophorous compost and green leaf lower the weed population in rice field due to allelopathic effect of compounds present in it. Report also available which shows that $P$. hysterophorous is rich in potash ${ }^{88}$.

\section{Parthenium hysterophorus for removal of heavy} metals

The soil and water pollution due to presence of heavy metal is one of the major environmental crises. Unlike organic compounds metals cannot be degraded and can easily enter food chain through absorption by plants causing health hazard. Various methods has been used for remediation, like excavation and landfill, thermal treatment, acid leaching and electroreclamation, but due to low efficiency, high cost, and large destruction of soil fertility and structure these approaches do not provide reasonable solutions ${ }^{89}$. One of the efficient biological processes for decontamination of soil is phytoremediation, which is the use of plants to extract, sequester, and detoxify pollutants. Phytoremediation includes phytoextraction, phytovolatilization, rhizofiltration, and phytostabilization ${ }^{90}$. The advantages of phytoremediation over other known process is its low cost, speed of deployment, preservation of natural soil properties, and reliance on solar energy ${ }^{91}$. The only backdraw of this process is that heavy metals can enter the food chain via animals grazing heavy metal-contaminated vegetation ${ }^{92}$. To overcome this backdraw, P. hysterophorus (Linn.) an unpalatable weed plant which reduce the chance of toxic metals entrance into the food chain. One study shows that $P$. hysterophorous for the remediation of lead contaminated soil. The study encouraged the use of gibberellic acid for lead phytoextraction by the weed $^{93}$.

Another study shows that the absorption of nickel from the aqueous solution by $P$. hysterophorus. It was concluded in the study that sulphuric acid treated carbonized Parthenium could be effective, low cost and easily available adsorbent for the removal of $\mathrm{Ni}$ (II) from dilute aqueous solution ${ }^{94}$. A study shows that dried powder of $P$. hysterophorus as an adsorbent for the removal of $\mathrm{Cd}$ from aqueous solution. The atomic absorbtion spectrophotometry of the filtrate obtained from batch process showed $P$. hysterophorous as an efficient absorbent of $\mathrm{Cd}$ (II). The maximum adsorption of $\mathrm{Cd}$ (II) ions was $99.7 \%$ when the $\mathrm{pH}$ range is 3-4. It was further showed by the desorption studies that $82 \%$ of $\mathrm{Cd}$ (II) can be recovered from the adsorbent when $0.1 \mathrm{M} \mathrm{HCl}$ solution is used as effluent ${ }^{95}$. Parthenium activated carbon is found to be equally effective as commercial 
grade activated carbon. It can be used as effective absorbent for $p$-cresol up to the concentration of $500 \mathrm{mg} / \mathrm{l}$ in aqueous medium ${ }^{96}$. Various reports are available which support biosorptive nature of $P$. hysterophorous weed for remove of methylene blue from dilute aqueous solution ${ }^{97}$ and $\mathrm{Cr}(\mathrm{VI})^{98}$.

\section{Miscellaneous Use}

In addition, Parthenium is the valuable source of potash, oxalic acid and high quality protein, which can be used in animal feed ${ }^{99}$. The dry leaf powder of $P$. hysterophorus causes wilting of the Salvinia molesta a weed, which cause a serious problem to aquatic creatures by choking the water bodies leading to its suffocation ${ }^{100}$. Another study shows that the use of $P$. hysterophorus in biogas production. The significant increase in methane content i.e upto $60-70 \%$ was achieved when $10 \%$ of weed is mixed with the cow dung ${ }^{101}$. A study shows that $P$. hysterophorus as a low cost raw material for the production of xylanase ${ }^{102}$. This weed is a source of potential energy ${ }^{103}$. Xylanases are hydrolytic enzyme which has various indrustrial applications. Phytochemical screening of $P$. hysterophorus showed the presence of different bio-constituents such as Alkaloids, Phenols, Flavonoids, Steroids, Cardiac Glycosides and Carbohydrates were present in ethanolic extract ${ }^{104}$. Free radical scavenging assay against the 1, 1-diphenyl-2-picryl-hydrazyl (DPPH) proved the strong antioxidant property of the plant ${ }^{105}$. The study shows that some P. hysterophorus extracts have various biological activities that could act synergistically against $H$. pylori ${ }^{106}$. Anticancer activity of parthenium phenolic extract against A-498 (IC50 $0.5237 \mathrm{ig} / \mathrm{ml}$ ) and MDA-MB231 (IC50 and 0.2685 $\mathrm{ig} / \mathrm{ml}$ ) cancerous cell lines indicated its potential to be used as anticancer agent ${ }^{107}$. Parthenium weed stem is boiled in water and used to remove the toothache and strong the gums. Ground root in water is used to remove boils and pimples. Its leaves extraction is used insomnia by pouring its drops in eyes ${ }^{108}$. It is carminative, leaves juice gives strength to the stomach and relief from constipation. Some people use it in fever also $P$. hysterophorus can be listed among various medicinal plants with potent antimicrobial property ${ }^{109}$. There are so many investigations reporting the antiviral, antifungal, antibacterial, antihelmintic, antimolluscal, and antiinflammatory properties of parthenium ${ }^{110,111}$. Antifungal property of $p$. hysterophorus has been reported by different investigators. Both plant and human pathogenic funguses viz., Fusarium Solani112,113. Alternaria Alternata ${ }^{114,115}$ Candidia albicans ${ }^{116}$ Fusarium oxysporium ${ }^{117}$ Aspergillus niger ${ }^{117,118,119}$ Aspergillus flavus ${ }^{120}$ Drechslera tetramera ${ }^{119}$ Phoma glomerata ${ }^{119}$ Aspergillus fumigates $^{121}$ Drechslera hawaiiensis, Alternaria alternate keiss ${ }^{122}$ Fusarium monilifrome ${ }^{122}$ Alternaria brassicae, Alternaria brassicicola ${ }^{123}$ Saccharomyces cerevisiae $^{120}$ Bipolaris oryzae ${ }^{124}$ were reported. Antibacterial efficacy of Parthenium hysterophorus has also been reported by various scientists as: Escherichia coli ${ }^{17}$ Bacillus subtilis, Enterococcus spp. ${ }^{125}$ Staphylococcus aureus ${ }^{118}$ Salmonella typhimurium, S. epidermidis, V. cholerae, Shigella flexneri'26 Pseudomonas aeruginosa ${ }^{114}$ Micrococcus luteus ${ }^{116}$ Bacillus cereus ${ }^{120}$ Klebsiella pneumoniae, Enterobactor aerogenes ${ }^{121}$ Xanthomonas vesicatoria, Ralstonia solanacearum ${ }^{111}$.

\section{CONCLUSION}

The rapid spread of parthenium has been a risk to the biodiversity, sustainable production of many crops, human health and livestock. Control of parthenium is therefore crucial to boost productivity of many crops as well as to overcome the loss of biodiversity. The parthenium can be kept control by enhancing its use in different aspects. Over exploitation of the weed for the beneficial use should be promoted for the proliferation of the $P$. hysterophorus. Research should be encouraged for the potential utilization of this weed. Parthenium as the raw material for the bio fuel is the future prospect. The increased utilization of weed as, insecticide, pesticide, composite and the raw material for enzyme production can change the weed from a curse to a boon for civilization.

\section{ACKNOWLEDGMENTS}

The Author acknowledges Graphic Era University for their support. 


\section{REFERENCES}

1. Khan et al. Oriental Journal of Chemistry. 2016, 32 (2),

2. Joshi et al. Oriental Journal of Chemistry. 2016, 32 (1), 331-340.

3. Nithya et al. Oriental Journal of Chemistry. 2015, 31 (4), 2319-2326.

4. Bajwa, R.; Shafique, S.; Anjum, T.; Shafique, S. International Journal of Agriculture \& Biology. 2004, 6, 511-516.

5. Navie, S.C.; Mcfadyen, R.E.; Panetta, F. D.; Adkins, S.W. Plant Protection Quaterly, 1996, 11 (2), 76-88.

6. Joshi, S. Plant Soil, 1991, 132, 213-218.

7. Williams, J.D.; Groves, R. H. Weed Res., 1980, 20, 47-52.

8. Dagar, J. C.; Rao, A. N.; Mall, L. P. Geobios, 1976, 3, 202-203.

9. Dale I. J.; Australian Weeds, 1981, 1, 8-14.

10. Rao, R.S.; J. Bombay Nat. Hist. Soc. 1956, 54, 218-220.

11. Nath, R.; Agricultural Review, 1988, 9, 171-179.

12. Tamado, T.; Schultz, W.; Milberg. P. Annals of Applied Biology, 2002, 140, 263-270.

13. Wakjira, M.; Berecha, G.; Tulu. S. African Journal of Agricultural Research, 2009, 4 (11), 1325-1330.

14. Mcconnachie, A. J.; Strathie, L. W.; Mersiet, W.; Gebrehiwott, L.; Zewdies, K.; A Abdurehim, A.; Abrha, B.; Araya, T.; Asaregew, F.; Assefa, F.; Gebre-Tsadik, R.; Nigatutt, L.; Tadesse, B.; Tanatt, T. Weed Research, 2010, 51, 71-84.

15. Patel, S. 3 Biotech, 2011, 1, 1-9.

16. Chhabra, B. R.; Kaushal, R.; Randhawa, H. S.; Dhillon, R. S. Fitoterapia 1998, 69(4), 374-375.

17. Chhabra, B. R.; Jain, M.; Bhullar, M. K. Indian Journal of Chemistry, Section B: Organic Chemistry Including Medicinal Chemistry. 1999, 38B(9), 1090-1092.

18. Das, R.; Sriitha, M.; Satyalakshmi, G.; Das, B. Indian journal of heterocyclic Chemistry, 2011, 20(3), 297-298.

19. Das, R.; Geethangili, M.; Majhi, A.; Das, B.; Rao, Y. K.; Tzeng, Y. M. Chemical and Pharmacological Bulletin, 2005, 53 (7), 861862.

20. Das, B.; Reddy, V. S.; Krishnaiah, M.; Sharma,
A. V. S.; Ravikumar, K.; Rao, J. V.; Sridhar, V. Phytochemistry, 2007, 68 (15), 2029-2034.

21. Das, B.; Gurram, M.; Rao, Y. K.; Chimmani, R.; Katta, V.; Krishnan, R.; Madamanchi, G.; Tzeng, Y. M. Helvetica Chimica Acta. 2006, 89.

22. Kalsi, P. S.; Mittal, V.; Singh, I. P.; Chhabra, B. R. Fitoterapia, 1995, 66(2), 191.

23. Sharma, S.; Gogia, S.; Madan, H. Journal of the Indian Chemical Society, 2010, 87(10), 1263-1266.

24. Madan, H.; Sharma, S. Journal of the Indian Chemical Society, 2011, 88(7), 10331036.

25. Ramesha, C.; Ravindranatha, N.; Dasa, B.; Ravikumara, K.; Kashinathamb, A.; McMorrisb, T. C.; Prabhakara, A.; Bharatam, J.; Phytochemistry, 2003, 841-844.

26. Venkataiah, B.; Ramesh, C.; Ravindranath, N.; Das, B. Phytochemistry 2003, 63, 383-386.

27. Chowdhury, A. R. Indian Perfumer. 2002, 46(1), 45-48.

28. Tobriya, S. K. International Journal of $R \& D$ in Engineering, Science and Management, 2015, 2(2), 10-15.

29. Narasimhan, Ô.R.; Ananth, İ.; Narayanaswamy, Ì.; Rajendra, B. M.; Mangala, A. S.; Subba Rao, P. V. Indian J. Anim. Sci., 1980, 50, 173.

30. Narasimhan, Ô. R.; Ananth, M.; Narayanaswamy, M.; Ranjendra Babu, M.; Mangala, A. S.; Subba Rao, P. V. Experentia, 1977, 33, 1358.

31. Tudor, G.D.; Ford, A.L.; Armstrong, T.R.; Bromagee, E.K. Australian J. Exptl. Agri. Animal Husbandry, 1982, 22, 43-46.

32. Gupta, B. K.; Sharma, K. K.; Kumar, S. International Journal of Pharmacology and Biological Sciences, 2010, 4(2), 127-132.

33. More, P. R.; Vadlamudi, V. P.; Qureshi, M. I. Indian Veterinary Medical Journal, 1988, 65 (5), 395-8.

34. Urmilesh, J.; Pritesh, M. C.; Tushar, T. S. Scholars Research Library, 2011, 3(4), 335341.

35. Maishi, A. I.; Ali, P. K. S.; Chaghtai, S. A.; Khan, G. Brit Homoeopath J. 1998, 87, 17-21.

36. Towers, G. H. N.; Subbha Rao, P.V. Weed 
science society of Victoria. 1992, 134-138.

37. Dipankar, C. R.; Munan, S. Journal of Medicinal Plants Studies, 2013, 1(3), 126141.

38. Agarwal, K. K.; D'Souza, M. Indian Clinical and Experimental Dermatology, 2009, 34(5), 4-6.

39. Lonkar, A.; Mitchell, J. C.; Colnan, C. D. Dermatalogical Society London, 1974, 60(7), 43-53.

40. Sanjeev, H.; Bijaylaxmi, S.; Vinod, K. S. Contact Dermatitis, 2001, 44, 279-282.

41. Nyasembe, V. O.; Cheseto, X.; Kaplan, F.; Foster, W. A.; Teal, P. E. A.; Tumlinson, J. H.; Borgemeister, C.; Torto, B.; PLOS ONE, 2015.

42. Srivastava, J. N.; Shukla, J. P.; Srivastava, R. C. Acta Bot. Indica, 1985, 13, 194-197.

43. Gopal Ji,; Shukla, S. K.; Dwivedi, P.; Sundaram, S.; Ebenso, E. E.; Prakash, R. Int. J. Electrochem. Sci., 2012, 7, 9933 - 9945.

44. Tamado, T.; Ohlander, L.; Milberg P. Int. J. Pest Manage, 2002, 48, 183-188.

45. Sinha, N. C.; Gupta, R. K.; Patil, B. D. Science and Culture, 1981, 47(5), 188-90.

46. Khosla, S. N.; Sobti, S. N. Pesticides, 1981, 15(3), 8-11.

47. Kumari, A.; Kohli, R. K.; Saxena, D. B. Annals Biol. 1985, 1, 189-196.

48. Sinha, V. S.; Nature, Environment and Pollution Technology, 2009, 8(4), 725-728.

49. Singh, H.P.; Batish, D.R.; Pandher, J. K.; Kohli, R. K. Weed Biol. Manag. 2005, 5, 105-109.

50. Raoof, K. M. A.; Siddiqui, M. B. Journal of the Saudi Society of Agricultural Sciences, 2012.

51. Pandey, D. K. J Chem Biol. 1994, 19, 26512662.

52. Swaminathan, C.; Rai, R. S.; Smesh, K. K. Int. Tree Crops J., 1990, 6, 143-150.

53. Riaz, T.; Javaid, A. The Journal of Animal and Plant Sciences, 2011, 21(3) 542-545.

54. Tefera, T. Journal of Agronomy and Crop Science, 2002, 188, 306-310.

55. Anwar, W.; Khan, S. N.; Tahira J. J.; Suliman, R. Pak. J. Weed Sci. Res. 2012, 18(1), 9197.

56. Yadav, A.; Garg, V. K. Bioresource Technology, 2011, 102, 5891-5895.

57. Chippendale, J. F.; Panetta, F. D. Plant Prot.
Q. 1994, 9, 73-76.

58. Palmer, W. A.; Heard, T.A.; Sheppard, A.W. Biological Control, 2010, 52, 271-287.

59. Evans, H.C. Biocontrol News and Information, 1997, 18, 89-98.

60. Javaid, A.; Anjum, T. Pak. J. Weed Sci. Res. 2005, 11 (3-4), 171-177.

61. Javaid, A.; Shah, M. B. M. The Philippine Agricultural, 2008, 91(4), 478-482.

62. Pandey, D. K. J. Chem. Ecol. 1996, 22, 151-160.

63. Shabbir, A,; Kunjitapatham, D,; O’Donnell C,; Adkins, S. W. Biological Control, 2012.

64. Binu, T.; Bharat, B S.; Maan, B. R. Flora, 2011, 206, 233-240.

65. Daizy, R. B.; Harminder, P. S.; Jasvir. K. P.; Weed Biology and Management, 2002, 2, 73-78.

66. Ayana, E.; Ensermu, K.; Teshome, S. Journal of Soil and Environmental Management, 2015, 6(5), 116-124.

67. Masum, S. M.; Ali, M. H.; Mandal, M. S. Journal of Weed Science, 2012, 3 (1\&2), 8390.

68. Asad, S.; Rukhsana, B. Weed Biology and Management, 2006, 6, 89-95.

69. Aslam, F.; Khaliq, A.; Matloob, A. The Journal of Animal and Plant Sciences, 2014, 24(1), 234-244.

70. Rajiv, P.; Narendhran, S.; Subhash, K. M. International Research Journal of Environment Sciences, 2013, 2(2), 1-5.

71. Mcfadyen, R. E. Crop Protection, 1992, 11, 405-407.

72. Das, B.; Venkataiah, B.; Kashinatham, A. Fitoterapia, 1999, 70, 101-102.

73. Patel, V. S.; Chitra, V.; Prasanna, P. L.; Krishnaraju, V. Indian J Pharmacol, 2008, 40(4), 183-185.

74. Mew, D.; Balza, F.; Towers, G. H. N.; Levy, I. G. Planta Medica, 1982, 45, 23-27.

75. Mukherjee, B.; Chatterjee, M. Planta medica, 1993, 59 (6), 513-6.

76. Sharma, G. L.; Bhutani, K. K. Planta Medica. 1988, 54, 20-22.

77. Sukanya, S. L.; Sudisha, J.; Hariprasad, P.; Niranjana S. R.; Prakash. H. S.; Fathima, S. K. African Journal of Biotechnology, 2009, 8(23), 6677-6682.

78. Acharyya, P.; Barua, N. C.; Sarma, A. Asian 
Journal of Microbiology, Biotechnology \& Environmental Sciences. 2008, 10(2), 281282.

79. Chen, Q.; Ouyang, M.; Xie, L.; Lin, Q. Jiguang Shengwu Xuebao. 2008, 17(4), 544-548.

80. Santhi, P R.; Anbusrinivasan, P. Asian Journal of Chemistry, 2008, 20(2), 987-991.

81. Kishore, P.; Ghosh, A. K.; Singh, S.; Maurya, B. R. Asian Journal of Agriculture Research. 2010, 4 (4), 220-225.

82. Javaid, A.; Shah, M. B. M. The Phililline Agricultural Scientist, 2008, 91(4), 478-482.

83. Isman, M. B.; Rodriguez, E. Phytochemistry, 1983, 22(12), 2709-2713.

84. Kumar, S.; Nair, G.; Singh, A. P.; Batra, S.; Wahab, N.; Warikoo, R. Asian Pacific Journal of Tropical Disease, 2012, 395-400.

85. Biradar, D. P.; Shivakumar, K. S.; Prakash, S. S.; Pujar, T. Karnataka J. Agric. Sci. 2006, 19, 256-263.

86. Channappagoudar, B. B.; Biradar, N. R.; Patil, J. B.; Gasimani, C. A. A. Karnataka J. Agric. Sci. 2007, 20, 245-248.

87. Belz, R. G.; Reinhardt, C. F.; Foxcroft, L. C. Crop Prot. 2007, 26, 237-245.

88. Marwat, S. K.; Rehman, F.; Khan, I. U.; Plant Science Today, 2015, 2(2), 77-81.

89. Jing, Y. D.; He Z. L.; Yang, X. E. J. Zhejiang Univ. Sci. 2007, 8, 192-207.

90. Chaney, R. L.; Malik, M.; Li Y. M.; Brown S. L.; Angle J. S.; Baker A. J. M. Curr. Opin. Biotechnol. 1997, 8, 279-284.

91. Zhuang, X. L.; Chen, J.; Shim, H.; Bai, Z. Environ. Int., 2007, 33, 406-413.

92. Seaward, M. R. D.; Richardson, D. H. S. CRC Press, Boca Raton, FL. 1993.

93. Hadi, F.; Bano, A. Weed Biology and Management, 2009, 9, 307-314.

94. Lata, H.; Garg, V. K.; Gupta, R. K. J Haz Mat. 2008, 157, 503-509.

95. Ajmal, M.; Rao, R. A. K.; Ahmad, R.; Khan, M. A. J. Haz. Mat. B. 2006, 135, 242-248.

96. Singh, R. K.; Kumar, S.; Kumar, S.; Kumar, A. J. Haz. Mat. 2008, 155, 523-535.

97. Lata, H.; Garg, V. K.; Gupta, R. K. Dyes Pigment, 2007, 74, 653-658.

98. Venugopal, V.; Mohanty K. Equilibrium, kinetics and thermodynamic studies" Chem. Eng. J. 2011, 174, 151-158.

99. Savangikar, V. A.; Joshi, R. N. Experimental
Agriculture, 1978, 14(1), 93- 4.

100. Pandey, D. K. J Chem Biol. 1994, 19, 26512662.

101. Gunaseelan, V. N. Biol Wastes, 1987, 21, 195-202.

102. Dwivedi, P.; Vivekanand, V.; Ganguly, R.; Singh, R. P. Biomass Energy, 2009, 33, 581-588.

103. Swati G,; Haldar S.; Ganguly A.; Chatterjee P. K. Renewable and Sustainable Energy Reviews, 2013, 20, 420-429.

104. Mane, J. D.; Jadav, S. J.; Ramaiah, N. A. J Agric Food Chem 1986, 34, 989-990.

105. Theeba, C. G.; Kumar, S. R. Journal of Chemical and Pharmaceutical Research, 2015, 7 (4), 219-225.

106. Espinosa, R. E.; Rendon, H. E.; Romero, I. PubMed-NCBI, 2015.

107. Panwar, R.; Sharma, A. K.; Dutt, D.; Pruthi, V. Advances in Bioscience and Biotechnology, 2015, 6, 11-17.

108. Noor, M. J.; Kalsoom, U. Pak. J. Bot. 2011, 43(2), 781-786.

109. Mahmood, A.; Qureshi, R. A.; Mahmood, A.; Sangi, Y.; Shaheen, H.; Ahmad, I.; Nawaz, Z. Journal of medicinal Plant Research, 2011, 5(18), 4493-4498.

110. Sesha, S. D. M.; Satyavathi, K.; Bhojaraju, P.; Pharmacophore, 2013, 4(6), 275-279.

111. Sukanya, S. L.; Sudisha J.; Hariprasad, P. African Journal of Biotechnology, 2009, 8(23), 6677-6682.

112. Shazia, S.; Sobiya, S. International Conference on Applied Life Sciences, 2012, 315-320.

113. Zunera, Z.; Shazia, S.; Sobiya, S. Scientific Research and Essays, 2012, 7(22), 20492054.

114. Singh, P.; Srivastava, D. International Research journal of Pharmacy, 2013, 4(7), 190-193.

115. Gaurav, K. P.; Brijesh, K.; Shahi, S. K. International Journal of Universal Pharmacy and Life Sciences, 2013, 3(2), 6-14.

116. Malarkodi, E.; Manoharan, A. Journal of Chemical and Pharmaceutical Research, 2013, 5(1), 137-139.

117. Harsha, M.; Santosh, G.; Sharda, S. Indian Journal of Natural Products and Resources, 2011, 2(4), 458-463.

188. Barsagade, N. B.; Wagh, G. N. Asiatic Journal 
of Biotechnology Resources, 2010, 3, 227232.

119. Rukhsana, B.; Afia, K.; Tabinda, S. C. Pakistan Journal of plant Pathology, 2003, 2(3), 145156.

120. Ajay, K.; Shailesh, J.; Tripti, M. International Journal of Life science Biotechnology and Pharma Research, 2013, 2(3), 232-236.

121. Rahmat, A. K.; Mushtaq, A.; Muhammad. R. African Journal of Pharmacy and Pharmacology, 2011, 5(18), 2073-2078.

122. Rukhsana, B.; Sobiya, S.; Tehmina, A. International Journal of Agriculture and
Biology, 2004, 6(3), 511-516.

123. Naina, S.;Archana, S. Journal of Environmental and Biological Science, 2012, 26(2), 133138.

124. Manimegalai, V.; Ambikapathy, V. Pelagia Research Library Der Pharmacia Sinica, 2012, 3(4), 507-510.

125. Hina, F.; Nisar, A.; Ikram, U. Pakistan Journal of Botany, 2011, 43(2), 1307-1313.

126. Siddhardha, B.; Ramakrishna, G.; Basaveswara, R. M. International Journal of Pharmaceutical, Chemical and Biological Sciences, 2012, 2(3), 206-209. 